\title{
MOTIVATIONAL FACTORS UNDERLYING THE USE OF ONLINE LEARNING SYSTEM IN HIGHER EDUCATION: AN ANALYSIS OF MEASUREMENT MODEL
}

\author{
Dr. Ridwan Daud MAHANDE \\ Orcid: 0000-0001-8427-978X \\ Faculty of Engineering \\ Universitas Negeri Makassar \\ Makassar, INDONESIA
}

AKRAM

Orcid: 0000-0002-1843-585X

Faculty of Teacher Training and Education

Universitas Muhammadiyah Makassar

Makassar, INDONESIA

Received: 20/02/2020 Accepted: 08/06/2020

\begin{abstract}
Online learning is a flexible and distributed distance learning system. The motivation of lecturers and students is one of key factors determining the acceptance and use of online learning in higher education. This research is aimed at empirically developing and testing a measurement model of several motivational constructs with the assumptions of indicators that build it. This research proposes a theoretical model which can be integrated into three motivational theories: ARCS, McClelland's needs, and Self-Determination Theory (SDT). The construct indicators were developed and then validated empirically at two universities in Makassar, Indonesia. A quantitative method with survey approach was used. The research sample consisted of 71 lecturers and 210 students selected purposively. The analysis of measurement models used partial least square (PLS). The results show that the construct of motivation with indicators that built it met validity and reliability requirements. The results of this research present two alternative instruments for explaining the relationship between motivational factors including the indicators that influence the use of online learning systems in tertiary institutions.
\end{abstract}

Keywords: Online learning system, motivational measurement; ARCS, McClelland's needs, SDT.

\section{INTRODUCTION}

Online learning has been prevalent throughout the world because it is considered potential to reduce time and distance problems in traditional education (Panigrahi et al., 2018; Bakia, Shear, Toyama, \& Lasseter, 2012; Hartnett, St. George, \& Dron, 2011). Nevertheless, studies conducted by researchers and literature studies confirm that motivation has been one of key factors inhibiting online learning (Hartnett et al., 2011; Shih, Chen, Chen, \& Wey, 2013). Motivation is a fundamental factor that requires further research and investigation. It is essential to understand and identify whether online learning can motivate lecturers and students (Huang \& Hew, 2016). Motivation is the inner power that moves and drives individuals to achieve goals (Mohamad, Salleh, \& Salam, 2015; Zainuddin, 2018; Vanslambrouck, Zhu, Lombaerts, Philipsen, \& Tondeur, 2018). The motivation of lecturers and students, which includes needs, beliefs, desires, and inner strengths, will stimulate certain activities (Raeisi et al., 2012). Therefore, every lecturer must have a high motivation to change teaching and learning styles in class, so that students' learning activities are more active, interesting, fun and competitive (Mohamad et al., 2015).

Research on online learning motivation with various topics, problems and methods has been conducted. Online learning motivation has been examined using the social cognitive theory (SCT) and attention-relevanceconfidence-satisfaction (ARCS) integration model (Taha \& Thang, 2014); self-regulated learning (SRL) and 
self-determination theory (SDT) integration models (Lin et al., 2017); motivation-opportunity-ability (MOA) and SDT (Lai et al., 2018); a single ARCS model (Mohamad et al., 2015); integrated models of ARCS and McLelland's theory of needs (Jokelova, 2013); a unique SDT model (Vanslambrouck et al., 2018; Zainuddin, 2018; Sergis, Sampson, \& Pelliccione, 2018a; Jacobi, 2018). This research integrated three motivational models, namely ARCS, McLelland's theory of needs and Self-Determination Theory (SDT). According to Keller (2008), the relevance factor of the ARCS model in accordance is by McClelland's theory of needs, and the confidence especially competence by SDT theory. The provides information that the three models can be integrated. Nevertheless, the integration of these three models has not attracted the attention of previous researchers. In this research, the researcher used three factors/constructs of the motivational model because the three motivational models complement each other and reinforce the assumptions of the indicators needed in the context of the problems that occur in the setting where this research was conducted. Specifically, this research aimed to empirically develop and test the measurement model of several motivational constructs on the assumptions of the indicators that built it. This research provides alternative instruments to investigate and obtain information related to online learning system motivation based on three basic theories of motivation.

This article is part of research on "Model of integrated motivation to explain the factors that influence the use of online learning systems in Higher Education". This research was funded by the Ministry of Research, Technology and Higher Education through National Competitive Basic Research grant. In the first year, this research aimed to develop and test motivational instruments by analyzing measurement models (reported in this article). The development of a questionnaire on motivation is very important for gathering information about factors that influence the use of online learning. Therefore, the focus of the first-year research is to provide alternative instruments to investigate and obtain information related to motivation for using online learning system based on indicators from three fundamental theories of motivation. After that, in the second year, the research aims to produce an integrated motivation model through structural equation models that are explored through qualitative methods (in the process). In the second year, the instruments that have been produced will be used to collect data about the use of online learning. Then, the structural relationships will be analysed (hypothesis testing). Hypothesis test results are confirmed through qualitative methods and analysis to produce an integrated motivation model that has been tested empirically.

\section{THEORETICAL FOUNDATIONS}

\section{Online Learning}

Online learning is a learning environment that is supported by the Internet. Online learning consists of various programs that use internet on and off-campus. Online learning can be fully online or mixed (blended) with face-to-face interaction (f2f) (Bakia et al., 2012). Online learning must provide learning. Therefore, institutions must ensure that lecturers and students are involved in the online learning process. The ideal online learning design should help lecturers and students maximize their intrinsic and extrinsic motivation, especially the hopes and needs of lecturers (Sarsar, 2012). Intrinsic motivation is presented when lecturers and students actively seek and participate in activities without having to be valued by the materials or activities outside the teaching assignment. Extrinsic motivation refers to motivation that comes from outside the individual (Mohamad et al., 2015).

\section{ARCS}

ARCS (Attention, Relevance, Confidence, Satisfaction) is a motivational model developed by John Keller (2008). The ARCS model effectively promotes online motivation, achievement, and independent learning (Chen \& Jang, 2010). Attention focuses on attention, builds curiosity, interest and is actively involved in learning activities (Keller, 2008; Keller, 2017). This attention is closely related to the interests of lecturers and students. Relevance focuses on concepts and strategies for building relationships in learning, which include content, teaching strategies, and social organization, as well as the objectives of teaching and learning, compatible with learning styles, and connected past experiences (Keller, 2017). According to Kellers, other motivational concepts that help explain relevance are motives such as the need for achievement, affiliation, and power (McClelland theory of needs) and competence. Competence in this study was taken from SelfDetermination Theory (SDT). 
Furthermore, the focus of relevance is to show the usefulness of content so that lecturers can bridge the gap between the content and real world. Confidence combines variables related to self-control and expectations for success. There is a correlation between the level of trust and positive expectations of success (Keller, 2017). Furthermore, Keller (2008) states that confidence covers some of the most popular motivational research areas, such as self-efficacy, attribution theory, and SDT. This research only used SDT. Satisfaction is needed by lecturers and students to have positive feelings about learning experiences and develop ongoing motivation for the learning process (Keller, 2008). Furthermore, Kellers states that extrinsic motivation, such as appreciation and recognition, must be used, and must not have a detrimental effect on intrinsic motivation. Lecturers and students must be satisfied with what they have achieved during the online learning process.

ARCS is important to be integrated based on concepts related to the value of needs and expectations (Sarsar, 2012), which have not been fully covered in ARCS theory. According to Sarsar (2012) that the concept of value refers to caring by explaining how certain types of goals are important for lecturers and students and influence their behavior (McCelland Integration Theory-Need for Achievement). Meanwhile, the concepts related to expectations refer to attention to questions about expectations for success (Integration with SDT-self efficacy and competence).

\section{Theory of McClelland's Needs}

McClelland's Theory of Needs is one of the most important theories for managers/leaders and academics to understand motivation (Turabik \& Baskan, 2015). McClelland mentions three basic needs that people get from life experiences: Need for Affiliation, Need for Power and Need for Achievement (Turabik \& Baskan, 2015; Vero \& Puka, 2017). Need for Affiliation is the desire to be friends and establish a warm relationship with others. Passive individuals will try to forgive and avoid interpersonal conflict at any time, even when it may be needed to fulfil a task (Turabik \& Baskan, 2015; Vero \& Puka, 2017; Jokelova, 2013). Need for Power is the desire to control others and influence behaviour (Vero \& Puka, 2017). Individuals have a desire to expand the source of power and authority and control all materials, spiritual resources (Turabik \& Baskan, 2015). Need for Achievement includes the desire to do better and to solve problems by taking personal responsibility, managing projects, showing full performance, needing fast feedback, and mastering complex or challenging tasks (Vero \& Puka, 2017; Turabik \& Baskan, 2015).

\section{Self-Determination Theory}

Self-determination Theory (SDT) is the framework of Ryan and Decy's motivational theory that offers provisions that enhance a sense of Autonomy, Competency, and Relatedness, which are supported by internal motivational factors, called intrinsic motivation (Zainuddin, 2018; Sergis et al., 2018b). SDT can be employed as a theoretical framework that integrates problems in online learning (Chen \& Jang, 2010). According to Ryan and Decy (quoted from Sergis et al. 2018b), Competency is related to the ability of lecturers and students to be involved in the learning process. Competence has a motivational aspect because individuals tend to feel competent and tend to find effective ways to deal with the environment (Jokelova, 2013). Autonomy related to the need to be involved with assignments autonomously in a context that is relevant to lecturers and students. Relatedness refers to the need to be involved in assignments that allow collaboration and communication with lecturers or among other students (Sergis et al., 2018b).

These three needs are essential for lecturers and students (Vero \& Puka, 2017). SDT is related to increasing interest, educational assessment, and confidence in the capacity and possessed technological attributes. These results are also the manifestations of motivation and internalization of intrinsic values and regulatory processes (Vero \& Puka, 2017).In SDT theory, motivation is divided into extrinsic and intrinsic motivation (Zainuddin, 2018). In this research, the researchers only used intrinsic motivation, because extrinsic motivation has been addressed by previous theories. More specifically, the resilience of SDT theory has not well established in online learning (Chen \& Jang, 2010). So, SDT should be integrated with other theories such as ARCS and McClelland's needs.

\section{RESEARCH METHODOLOGY}

This research used quantitative method with survey approach. Survey approach is aimed to obtain information about a group of people to study their characteristics, opinions, attitudes, or experiences by asking them 
questions and compiling their answers (Leedy \& Ormrod, 2016). The survey was conducted at two universities in Indonesia, namely Universitas Negeri Makassar (UNM) and Universitas Muhammadiyah Makassar (Unismuh). The research respondents consisted of 71 lecturers and 210 students selected purposively.

Purposive sampling technique was used for selecting the participants. The requirements for determining the participants were lecturers and students who had and or always used online learning services in teaching and learning activities, also lecturers and students who had attended training related to online learning.

The variables of this study consisted of eight exogenous variables; those were variables that influenced other variables and three endogenous variables; those were influenced by other variables. The eight exogenous variables are attention (AT), satisfaction (Sas), need for affiliation (nAff), need for power (nPow), need for achievement (nAch), Autonomy (Au), Competency (Com), and Relatedness (RL). Meanwhile, the three endogenous variables are Motivation for using online learning $(\mathrm{MuOL})$, Relevance $(\mathrm{Rv})$, and Confidence (Con). The proposed structural equation model of online learning motivation is presented in Figure 1 below:

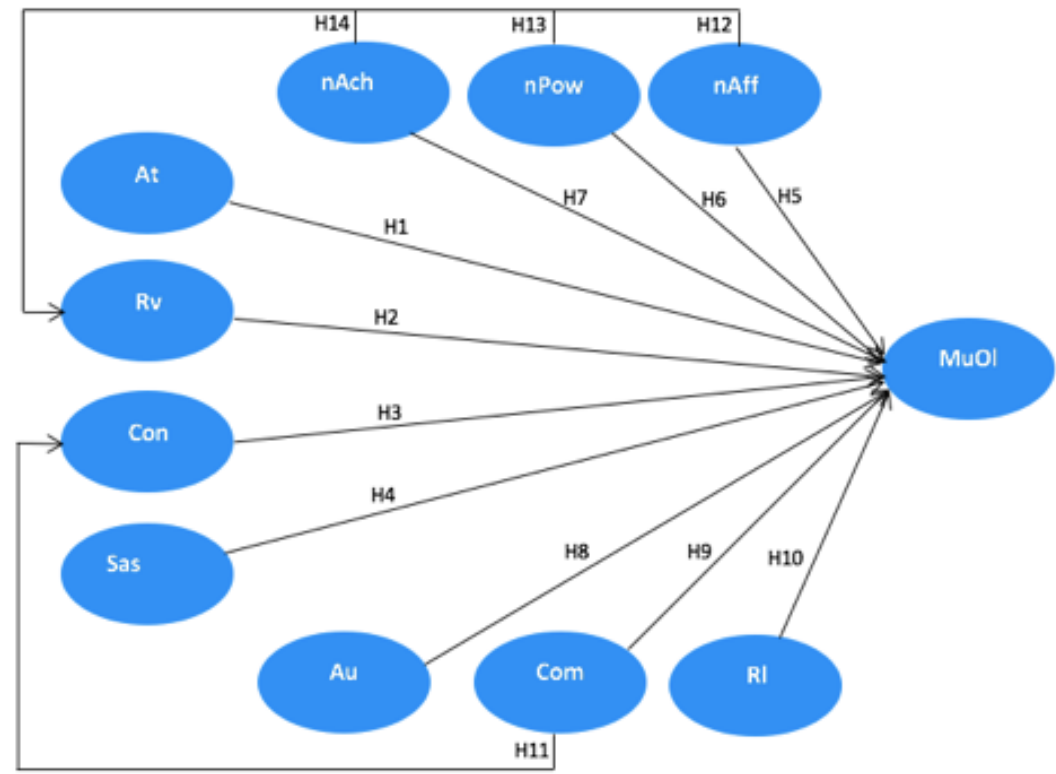

Note: At=Attention; Rv=Relevance; Con=Confidence; Sas=Satisfaction; $n A f f=$ need for Affiliation; $n$ Pow $=$ need for Power; $n A c h=$ need for Achievement; $A u=$ Autonomy; Com=Competency; $R l=$ Relatedness; $M u O l=$ Motivation of use online learning

Figure 1. Structural equation model of motivation for using online learning

This research developed and validated the survey research instrument in the form of questionnaire, which assessed the construct of motivation for using online learning in tertiary institutions. The questionnaire used derived from the integration of three motivational theories of ARCS, McClelland needs, and Self-Determination Theory (SDT). The questionnaire consisted of the constructs/factors of attention, relevance, confidence, satisfaction (ARCS theory), need for affiliation, need for power, need for achievement (Theory McClelland needs), autonomy, competence and relatedness (SDT theory) and motivation of using online learning.

The development of the research questionnaire focused on the items/indicators of each construct (see Table 1). Items/indicators were developed without changing the constructs of the three fundamental theories of motivation used. The questionnaire used a 4-point Likert scale from strongly disagree to strongly agree. After the questionnaire was developed, then content validity was measured. Content diversity was carried out by three experts from different fields: (1) ICT-based learning, (2) online learning, cognitive systems, selfregulated learning, and (3) informatics engineering education-technology acceptance education.

Furthermore, empirical data collection used a questionnaire. The questionnaire was provided online (on Google form). The data were collected using the questionnaire online. All respondents were informed about the aims and contributions of the research, so that the respondents agreed voluntarily to participate. The questionnaire was completely anonymized. No personal information was requested from respondents and no tracking system was used. To recruit the respondents and minimize bias, personal identities and data were kept confidentially. 
Table 1. The construct of motivation integrated into the use of online learning

\begin{tabular}{|c|c|c|}
\hline Theoretical Supports & Constructs & Indicators/items \\
\hline \multirow{18}{*}{$\begin{array}{l}\text { ARCS theory } \\
\text { (Keller, 2008); Taha } \\
\text { \& Thang, 2014); } \\
\text { Huang \& Hew, 2016) }\end{array}$} & \multirow{5}{*}{$\begin{array}{l}\text { Attention } \\
\text { (At) }\end{array}$} & Online learning system and design attract attention (At1) \\
\hline & & Online learning content can build curiosity (At2) \\
\hline & & More interactive online learning (At3) \\
\hline & & Online learning using learning methods that are of interest (At4) \\
\hline & & More interesting online assignments and exercises (At5) \\
\hline & \multirow{4}{*}{$\begin{array}{l}\text { Relevance } \\
\text { (Rv) }\end{array}$} & Online learning relevant to the demands of current learning (Rv1) \\
\hline & & $\begin{array}{l}\text { Online learning strategies and methods in accordance with the learning } \\
\text { achievements (Rv2) }\end{array}$ \\
\hline & & Online learning content relevant to learning outcomes (Rv3) \\
\hline & & Adaptive-engaging online learning content (Rv4) \\
\hline & \multirow{5}{*}{$\begin{array}{l}\text { Confidence } \\
\text { (Con) }\end{array}$} & Online learning increases knowledge (Con1) \\
\hline & & Online learning is the key to success in the future (Con2) \\
\hline & & Online learning provides a good learning experience (Con3) \\
\hline & & Online learning userfriendly learning (Con4) \\
\hline & & Online learning provides meaningful feedback (Con5) \\
\hline & \multirow{7}{*}{$\begin{array}{l}\text { Need for } \\
\text { Affiliation } \\
\text { (nAff) }\end{array}$} & The convenience of learning through online learning (Sas1) \\
\hline & & Received an award/recognition from online learning implementation (Sas2) \\
\hline & & The pleasure of completing an online learning course (Sas3) \\
\hline & & Structured and systematic online learning design (Sas4) \\
\hline \multirow{11}{*}{$\begin{array}{l}\text { McClelland's needs } \\
\text { theory (Turabik } \\
\text { \& Baskan, 2015; } \\
\text { Raeisi, Hadadi, } \\
\text { Faraji, \& Salehian, } \\
\text { 2012power and } \\
\text { affiliation; Moore, } \\
\text { Grabsch, \& Rotter, } \\
\text { 2010; Vero \& Puka, } \\
\text { 2017) }\end{array}$} & & The desire to collaborate through online learning (nAff1) \\
\hline & & The desire to fulfil tasks through online learning (nAff2) \\
\hline & & The desire to build close relationships through online learning (nAff3) \\
\hline & \multirow{4}{*}{$\begin{array}{l}\text { Need for } \\
\text { Power } \\
\text { (nPow) }\end{array}$} & The desire of institutions that require online learning (nPow1) \\
\hline & & Desire yourself to use online learning (nPow2) \\
\hline & & The desire to obtain the highest position from the use of online learning (nPow3) \\
\hline & & The desire to become an online learning system manager at an institution (nPow4) \\
\hline & \multirow{4}{*}{$\begin{array}{l}\text { Need for } \\
\text { Achievement } \\
\text { (nAch) }\end{array}$} & The desire to do something more than ordinary learning (nAch1) \\
\hline & & Solve online learning problems (nAch2) \\
\hline & & Taking personal responsibility in using online learning (nAch3) \\
\hline & & Demonstrating good performance in online learning (nAch4) \\
\hline \multirow{21}{*}{$\begin{array}{l}\text { Self-Determination } \\
\text { (SDT) Theory } \\
\text { (Sergis, Sampson, } \\
\text { \& Pelliccione, 2018; } \\
\text { Jacobi, 2018) }\end{array}$} & \multirow{4}{*}{$\begin{array}{l}\text { Autonomy } \\
\quad(\mathrm{Au})\end{array}$} & Essential and useful online learning (Au1) \\
\hline & & Online learning is very flexible (Au2) \\
\hline & & Have control of learning to decide what should and should not be done (Au3) \\
\hline & & An explanation is provided along with examples of using online learning (Au4) \\
\hline & \multirow{3}{*}{$\begin{array}{l}\text { Competency } \\
\text { (Com) }\end{array}$} & Have the ability to engage in online learning (Com1) \\
\hline & & $\begin{array}{l}\text { Able to meet the learning achievements that are the targets of online learning } \\
\text { (Com2) }\end{array}$ \\
\hline & & Able to access and spell questions online (Com3) \\
\hline & \multirow{4}{*}{$\begin{array}{l}\text { Relatedness } \\
\quad(\mathrm{Rl})\end{array}$} & $\begin{array}{l}\text { Collaboration and communication related to learning and assignments through } \\
\text { online education (R1) }\end{array}$ \\
\hline & & Feel closer to and/or fellow lecturers (RI2) \\
\hline & & Interact more often with friends (RI3) \\
\hline & & Actively contributing throughout the class in group activities (R4) \\
\hline & \multirow{10}{*}{$\begin{array}{l}\text { The } \\
\text { motivation } \\
\text { to use the } \\
\text { online } \\
\text { learning } \\
\text { system } \\
\text { (MuOI) }\end{array}$} & Attention to online learning (MuOl1) \\
\hline & & The relevance of online learning ( $\mathrm{MuOl} 2)$ \\
\hline & & Trust in online learning (MuOl3) \\
\hline & & Satisfaction with online learning (MuOl4) \\
\hline & & Affiliated needs through online learning (MuOI5) \\
\hline & & The need to control through online learning (MuOl6) \\
\hline & & Achievement needs of using online learning (MuOl7) \\
\hline & & Autonomy online learning (MuOl8) \\
\hline & & Online learning competencies (MuOl9) \\
\hline & & Linkages online learning (MuOl10) \\
\hline
\end{tabular}

Note. Using a four-point scale $1=$ strongly disagree, $2=$ disagree, $3=$ agree, $4=$ strongly agree, the constructs were to be measured by asking lecturers and students to rate their perceptions of online learning system in higher education 


\section{ANALYSIS AND RESULTS}

Data analysis in this research used structural equation modelling (SEM) with SmartPLS software. PLSSEM is a powerful method for analyzing complex models with smaller samples (Meyliana et al., 2019). In SEM analysis, there are two stages. First, the analysis of the measurement models was to test the validity and reliability of the instrument. Second, the analysis of structural models was to test hypotheses (Meyliana et al., 2019). In this article, SEM analysis was only applied to the presentation of measurement model results. Measurement models were used to establish appropriate indicators for measuring latent constructs (Jöreskog \& Sörbom, 1993). In this view, the analysis of measurement model was used to test the validity and reliability of the instrument by considering the relationship of latent constructs of motivation with the indicators that build it. The measurement model used a reflective indicator model.

\section{Reflective Measurement Model Analysis}

The analysis of measurement model used reflective indicator model. Reflective indicators are manifestations of a latent construct (Santosa, 2018). Reflective indicators are used to constructs (Cidral et al., 2018). The quality of the reflective measurement model is determined based on validity and reliability (Ringle et al., 2012). The assessment of the validity and reflective reliability is based on the reliability indicator seen from item/indicator loading; the internal reliability consistency is seen from composite reliability and Cronbach's alpha. Convergent validity is seen from AVE, and discriminant validity is through Fornell-Larcker criteria and cross-loadings (Ringle et al., 2012; Hair, 2017). Internal consistency values are in the range of 0 and 1 (Hair, 2017). The higher the internal consistency value, the higher the level of reliability. Internal consistency criteria through construct reliability of 0.70 (Nunnaly \& Bernstein, 1994; Barclay, Higgins, \& Thompson, 1995; Hair, 2017) are interpreted similar to Cronbach's alpha. Likewise, the reliability indicator is determined by an outer loading value higher than 0.70 (Hair, 2017). Convergent validity is a measure that shows how far an indicator is positively correlated with other indicators in the same construct (Santosa, 2018). Convergent validity through average variance extracted (AVE) must be higher than 0.50 (Hair, 2017). Discriminant validity is a measure that shows a construct that is different from other constructs (Santosa, 2018). Discriminant validity is tested at the indicator and construct levels. Discriminant validity is at the indicator level with cross-loadings. Outer loading indicators for a construct must be higher than all cross-loadings in other constructs (Barclay et al., 1995; Hair, 2017). At the construct level, the discriminant validity is tested by comparing the square root AVE of a construct with the correlation of construct with other constructs. Specifically, the square root 
Table 2. The result analysis of reflective measurement model

\begin{tabular}{|c|c|c|c|c|c|c|c|c|c|}
\hline \multirow[t]{2}{*}{$\begin{array}{l}\text { Constructs/ } \\
\text { Factors }\end{array}$} & \multirow[t]{2}{*}{ Items } & \multicolumn{2}{|c|}{ Outer Loadings } & \multicolumn{2}{|c|}{$\begin{array}{c}\text { Composite Reliability } \\
\text { (CR) }\end{array}$} & \multicolumn{2}{|c|}{ Cronbach's Alpha } & \multicolumn{2}{|c|}{$\begin{array}{l}\text { Average Variance } \\
\text { Extracted (AVE) }\end{array}$} \\
\hline & & Lecturers & Students & Lecturers & Students & Lecturers & Students & Lecturers & Students \\
\hline \multirow{5}{*}{$\begin{array}{l}\text { Attention } \\
\text { (At) }\end{array}$} & At1 & Out & 0.789 & 0.876 & 0.883 & 0.725 & 0.824 & 0.780 & 0.665 \\
\hline & At2 & Out & 0.833 & & & & & & \\
\hline & At3 & 0.844 & 0.784 & & & & & & \\
\hline & At4 & 0.921 & 0.829 & & & & & & \\
\hline & At5 & Out & Out & & & & & & \\
\hline \multirow{4}{*}{$\begin{array}{l}\text { Relevance } \\
\text { (Rv) }\end{array}$} & $\mathrm{Rv} 1$ & Out & 0.770 & 0.896 & 0.900 & 0.826 & 0.852 & 0.741 & 0.694 \\
\hline & $\mathrm{Rv} 2$ & 0.830 & 0.857 & & & & & & \\
\hline & Rv3 & 0.874 & 0.877 & & & & & & \\
\hline & Rv4 & 0.878 & 0.824 & & & & & & \\
\hline \multirow{5}{*}{$\begin{array}{l}\text { Confidence } \\
\text { (Con) }\end{array}$} & Con1 & 0.789 & 0.751 & 0.882 & 0.838 & 0.823 & 0.744 & 0.653 & 0.565 \\
\hline & Con2 & Out & Out & & & & & & \\
\hline & Con3 & 0.873 & 0.768 & & & & & & \\
\hline & Con4 & 0.767 & 0.741 & & & & & & \\
\hline & Con5 & 0.798 & 0.745 & & & & & & \\
\hline \multirow{4}{*}{$\begin{array}{l}\text { Satisfaction } \\
\text { (Sas) }\end{array}$} & Sas1 & 0.846 & 0.770 & 0.872 & 0.872 & 0.806 & 0.805 & 0.632 & 0.631 \\
\hline & Sas2 & 0.798 & 0.813 & & & & & & \\
\hline & Sas3 & 0.775 & 0.822 & & & & & & \\
\hline & Sas4 & 0.757 & 0.770 & & & & & & \\
\hline \multirow{3}{*}{$\begin{array}{l}\text { Need for } \\
\text { Affiliation } \\
\text { (nAff) }\end{array}$} & nAff1 & 0.874 & 0.819 & 0.918 & 0.870 & 0.865 & 0.776 & 0.788 & 0.690 \\
\hline & nAff2 & 0.888 & 0.830 & & & & & & \\
\hline & nAff3 & 0.901 & 0.843 & & & & & & \\
\hline \multirow{4}{*}{$\begin{array}{c}\text { Need for } \\
\text { Power (nPow) }\end{array}$} & nPow1 & Out & 0.848 & 0.869 & 0.884 & 0.780 & 0.804 & 0.688 & 0.718 \\
\hline & nPow2 & 0.823 & 0.852 & & & & & & \\
\hline & nPow3 & 0.843 & 0.841 & & & & & & \\
\hline & nPow4 & 0.823 & Out & & & & & & \\
\hline \multirow{4}{*}{$\begin{array}{c}\text { Need for } \\
\text { Achievement } \\
\text { (nAch) }\end{array}$} & nAch1 & 0.838 & 0.748 & 0.888 & 0.895 & 0.810 & 0.844 & 0.726 & 0.682 \\
\hline & nAch2 & 0.914 & 0.836 & & & & & & \\
\hline & nAch3 & 0.801 & 0.852 & & & & & & \\
\hline & nAch4 & Out & 0.863 & & & & & & \\
\hline \multirow{4}{*}{$\begin{array}{l}\text { Autonomy } \\
\text { (Au) }\end{array}$} & Au1 & 0.878 & 0.858 & 0.868 & 0.884 & 0.771 & 0.803 & 0.688 & 0.718 \\
\hline & Au2 & 0.848 & 0.867 & & & & & & \\
\hline & Au3 & 0.757 & 0.816 & & & & & & \\
\hline & Au4 & Out & Out & & & & & & \\
\hline \multirow{3}{*}{$\begin{array}{l}\text { Comptency } \\
\text { (Com) }\end{array}$} & Com1 & 0.850 & 0.886 & 0.862 & 0.918 & 0.798 & 0.866 & 0.713 & 0.788 \\
\hline & Com2 & 0.811 & 0.905 & & & & & & \\
\hline & Com3 & 0.871 & 0.873 & & & & & & \\
\hline \multirow{4}{*}{$\begin{array}{l}\text { Relatedness } \\
\quad(\mathrm{RI})\end{array}$} & RI1 & Out & 0.766 & 0.902 & 0.878 & 0.836 & 0.817 & 0.755 & 0.642 \\
\hline & $\mathrm{R} / 2$ & 0.838 & 0.798 & & & & & & \\
\hline & $\mathrm{RI} 3$ & 0.933 & 0.819 & & & & & & \\
\hline & $\mathrm{RI} 4$ & 0.832 & 0.821 & & & & & & \\
\hline \multirow{10}{*}{$\begin{array}{l}\text { The } \\
\text { motivation to } \\
\text { use the online } \\
\text { learning } \\
\text { system } \\
\text { (MoUl) }\end{array}$} & MuOl1 & 0.729 & 0.789 & 0.934 & 0.943 & 0.918 & 0.932 & 0.638 & 0.622 \\
\hline & $\mathrm{MuOl} 2$ & Out & 0.783 & & & & & & \\
\hline & MuOl3 & 0.732 & 0.790 & & & & & & \\
\hline & $\mathrm{MuOl} 4$ & 0.790 & 0.775 & & & & & & \\
\hline & MuOl5 & 0.811 & 0.764 & & & & & & \\
\hline & MuOl6 & Out & 0.816 & & & & & & \\
\hline & MuOl7 & 0.850 & 0.817 & & & & & & \\
\hline & MuOl8 & 0.810 & 0.789 & & & & & & \\
\hline & MuOl9 & 0.827 & 0.771 & & & & & & \\
\hline & MuOl10 & 0.833 & 0.788 & & & & & & \\
\hline
\end{tabular}

Note. The loading value of items marked "out" is excluded because they do not meet the criteria $<0.70$. 
The results of the reflective measurement model analysis presented in Table 2 show that the outer loading value for each construct item/indicator from the results of the lecturer and student assessment was above the minimum value of 0.70 . Because all results were higher than 0.70 , the indicators are proven reliable (Hair, 2017). However, there were some items/indicators that were marked "out" (See Table 2 for lecturer and student outer loadings columns). These items did not meet the loading value that had become the criterion, or the held value that was only around 0.50-0.69. Indicators with outer loading between 0.40 and 0.70 should be considered as eliminated only if the deletion leads to an increase in composite reliability and AVE, more than the recommended threshold value (Hair, 2017). This happens after the data had been analyzed. Besides, the outer loading value does not meet the standard; the outer loading value also leads to an increase in composite reliability and AVE. If it is not removed, it will have a negative impact on reliability. Therefore, indicators with outer loading must be removed/deleted.

However, taking into account different opinions about loading criteria, namely the internal consistency value of 0.50 for new instruments that have not been tested (Fornell \& Larcker, 1981), the internal consistency value of $0.60-0.70$ is acceptable for exploratory research (Hair, 2017). Therefore, the researchers presented the outer loading value of item/indicator as a reference for future research. Besides, there was one item/ indicator on the student assessment that the researchers excluded despite the value of 0.70 (nPow4). This was because these items affected the validity of discriminant, both constructs and indicators. After exploring through further verification, the question was less relevant and biased to be empirically assessed by students. All constructs had composite reliability and Cronbach alpha above 0.70 which means that all constructs are reliable because they meet the criteria (Nunnaly \& Bernstein, 1994; Barclay et al., 1995; Hair, 2017). Analyzing convergent validity, the researchers calculated AVE. The results of the analysis in Table 2 show that all AVE was higher than 0.50. The AVE value must be greater than 0.50 to explain more than half of the indicator variants (Hair, 2017).

The next, was discriminant validity. Discriminant validity at the construct level is presented in Table 3 (lecturer) and Table 4 (student), and at the indicator level is presented in Appendix B. To analyze discriminant validity at the indicator level, the researchers compared all loading items (bold) with cross-loadings such as shown in Appendix B. As a result, all items/indicators that met the criteria of outer loading indicator for constructs must be higher than all cross-loadings in other constructs (Barclay et al., 1995; Hair, 2017). At the construct level (see Tables 3 and 4), it showed that all constructs meet the validity criteria which require that all square roots of AVE (bolded) must be higher than correlations among other constructs (Fornell \& Larcker, 1981)

Table 3. Descriptive, correlation constructs, and the square root of AVE of Lecturers data analysis

\begin{tabular}{lrcccccccccccc}
\hline & Mean & SD & At & Au & Com & Con & MuOl & Rl & Rv & Sas & nAch & nAff & nPow \\
\hline At & 6.57 & 1.261 & $\mathbf{0 . 8 8 3}$ & & & & & & & & & & \\
Au & 10.65 & 1.445 & 0.446 & $\mathbf{0 . 8 2 9}$ & & & & & & & & & \\
Com & 10.38 & 1.467 & 0.554 & 0.594 & $\mathbf{0 . 8 4 4}$ & & & & & & & & \\
Con & 13.25 & 2.054 & 0.527 & 0.524 & 0.589 & $\mathbf{0 . 8 0 8}$ & & & & & & & \\
MuOI & 26.46 & 3.898 & 0.596 & 0.646 & 0.727 & 0.595 & $\mathbf{0 . 7 9 9}$ & & & & & & \\
Rl & 8.85 & 1.892 & 0.567 & 0.469 & 0.491 & 0.410 & 0.654 & $\mathbf{0 . 8 6 9}$ & & & & & \\
Rv & 9.93 & 1.718 & 0.639 & 0.493 & 0.626 & 0.588 & 0.588 & 0.539 & $\mathbf{0 . 8 6 1}$ & & & & \\
Sas & 13.32 & 1.962 & 0.547 & 0.708 & 0.791 & 0.562 & 0.774 & 0.626 & 0.640 & $\mathbf{0 . 7 9 5}$ & & & \\
nAch & 10.52 & 1.491 & 0.506 & 0.629 & 0.703 & 0.511 & 0.751 & 0.415 & 0.437 & 0.694 & $\mathbf{0 . 8 5 2}$ & & \\
nAff & 10.42 & 1.713 & 0.449 & 0.568 & 0.613 & 0.561 & 0.657 & 0.539 & 0.561 & 0.685 & 0.605 & $\mathbf{0 . 8 8 8}$ & \\
nPow & 10.141 & 1.650 & 0.536 & 0.557 & 0.628 & 0.525 & 0.712 & 0.473 & 0.506 & 0.674 & 0.769 & 0.633 & $\mathbf{0 . 8 3 0}$ \\
\hline
\end{tabular}

Note. Attention (At), Relevance (Rv), Confidence (Con), Satisfaction (Sas), need for Affliation (nAff), need for Power (nPow), need for Achievement (nAch), Autonomy (Au), Competency (Com), Relatedness (Rl), Motivation of Use online learning (MoUl) 
Table 4. Descriptive, correlation constructs, and the square root of AVE of Students data analysis

\begin{tabular}{lccccccccccccc}
\hline & Mean & SD & At & Au & Com & Con & MuOl & Rl & Rv & Sas & nAch & nAff & nPow \\
\hline At & 13.362 & 2.278 & $\mathbf{0 . 8 0 9}$ & & & & & & & & & & \\
Au & 9.971 & 1.711 & 0.559 & $\mathbf{0 . 8 4 7}$ & & & & & & & & & \\
Com & 9.924 & 1.710 & 0.580 & 0.649 & $\mathbf{0 . 8 8 8}$ & & & & & & & & \\
Con & 13.081 & 2.023 & 0.698 & 0.666 & 0.623 & $\mathbf{0 . 7 5 1}$ & & & & & & & \\
MuOI & 32.000 & 5.503 & 0.677 & 0.750 & 0.723 & 0.726 & $\mathbf{0 . 7 8 8}$ & & & & & & \\
Rl & 12.324 & 2.677 & 0.601 & 0.572 & 0.687 & 0.630 & 0.736 & $\mathbf{0 . 8 0 1}$ & & & & & \\
Rv & 12.819 & 2.337 & 0.773 & 0.627 & 0.585 & 0.732 & 0.697 & 0.563 & $\mathbf{0 . 8 3 3}$ & & & & \\
Sas & 13.243 & 2.099 & 0.669 & 0.611 & 0.663 & 0.721 & 0.749 & 0.676 & 0.684 & $\mathbf{0 . 7 9 4}$ & & & \\
nAch & 13.229 & 2.385 & 0.556 & 0.717 & 0.645 & 0.677 & 0.759 & 0.596 & 0.607 & 0.637 & $\mathbf{0 . 8 2 6}$ & & \\
nAff & 9.848 & 1.743 & 0.615 & 0.633 & 0.585 & 0.690 & 0.716 & 0.588 & 0.619 & 0.745 & 0.683 & $\mathbf{0 . 8 3 1}$ & \\
nPow & 9.629 & 1.893 & 0.614 & 0.662 & 0.623 & 0.655 & 0.764 & 0.643 & 0.620 & 0.720 & 0.668 & 0.773 & $\mathbf{0 . 8 4 7}$ \\
\hline
\end{tabular}

Note. Attention (At), Relevance (Rv), Confidence (Con), Satisfaction (Sas), need for Affiliation (nAff), need for Power (nPow), need for Achievement (nAch), Autonomy (Au), Competency (Com), Relatedness (Rl), Motivation of Use online learning (MoUl)

\section{CONCLUSION, LIMITATIONS AND IMPLICATIONS}

This article has presented theoretical background that includes the barriers toward acceptance and online learning usage caused by motivational factors. Based on the integrated motivation theory, the measurement model was proposed and validated empirically. This research shows that the constructs of motivation with the indicators that built them fulfilled the validity and reliability requirements. The results of research presented two alternative instruments (See Appendix C and D) to explain the relationship among motivational factors including the indicators that influenced the online learning system usage in tertiary institutions. These two instruments begin with a common motivational construct and the items/indicators that build it. However, the results of the analysis show that the items/indicators of construct motivation for lecturers and students are different. This means, there are items/indicators that better represent the construct of motivation when when both by the lecturers and students. Therefore, the results of this study indicate that lecturers' instruments are only used to collect information from lecturers. Likewise, student instruments are used to obtain information from students. The instrument was used separately in the context of this study only. However, in other research contexts, this instrument could have been used to collect data from the same and different objects but had to go through a re-measurement analysis.

This study has some limitations. First, it only involved two institutions with a small sample, making it challenging to generalise the results to broader contexts. Nevertheless, the results of this study provide a reference instrument that can be developed, used and tested on a large scale. Second, this first-year research was only focused on the analysis of the measurement model and the presentation of the structural model (Figure 1), it has not dealt with the empirical analysis of the structural model. So, the motivational factors for the use of online learning systems cannot be answered. Further research (second year) will conduct an empirical analysis of structural models and confirm the results of the investigation through a qualitative approach. Nevertheless, this study also presents a structural model so that other researchers can adopt the model and test it in different research contexts.

This research presents theoretical and practical implications. In terms of theoretical implications, this study integrates ARCS theory, McLelland's needs theory, and Self-Determination Theory. The integration of items/ indicators of the three motivational theories can represent the information needed to answer the motivational factors for using an online learning system. In terms of practical implications, this study validates three motivational theories consisting of ten constructs with indicators that build them through research focusing on the use of online learning systems in the context of two tertiary institutions in Makassar, Indonesia. Thus, the instrument can be used as a reference for higher education to investigate and obtain information related to motivation for using online learning system based on three fundamental theories of motivation. 
Acknowledgements: This research was funded by the Ministry of Research, Technology and Higher Education through National Competitive Basic Research grant. The authors also thanks to Prosemantic.com for proofreading the manuscript.

\section{BIODATA and CONTACT ADDRESSES of AUTHORS}

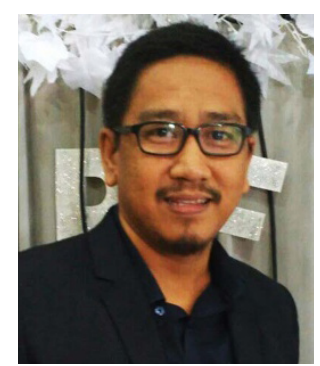

Dr. Ridwan Daud MAHANDE, M.Pd., is an assistant professor in the Informatics and Computer Engineering Education Department, Universitas Negeri Makassar, Indonesia. $\mathrm{He}$ is a temporary lecturer in Educational Technology Department, Universitas Muhammadiyah Makassar, Indonesia. He received his doctorate degree in the field of Technology and Vocational Education from Graduate School Universitas Negeri Yogyakarta, Indonesia. His research interest is learning of vocational information technology, e-learning, technology acceptance, multimedia learning.

Ridwan Daud MAHANDE

Department of Informatics and Computer Engineering Education,

Faculty of Engineering

Address: Universitas Negeri Makassar, Faculty of Engineering,

Jl. Dg. Tata Raya Parangtambung Makassar, South Sulawesi.

Phone: (+62) 81355425094

Email: ridwandm@unm.ac.id

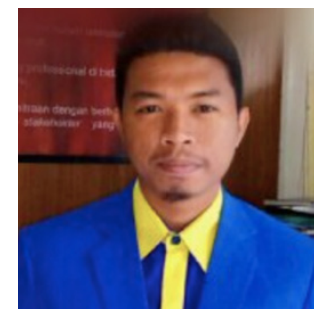

AKRAM,S.Pd., M.Pd., is an assistant professor in Educational Technology Department, Universitas Muhammadiyah Makassar, Indonesia. He received his Bachelor degree in the field of Educational Technology from Universitas Muhammadiyah Makassar, Indonesia. He earned his Master degree in the field of Technology and Vocational Education from Postgraduate Program, Universitas Negeri Makassar, Indonesia. His research interest is multimedia learning and computer education

\section{AKRAM}

Department of Education Technology,

Faculty of Teacher Training Education

Address: Universitas Muhammadiyah Makassar, Faculty of Teacher Training Education,

Jl. Sultan Alauddin No. 259 Makassar, South Sulawesi. Postal Code 90221

Phone: (+62) 85399353128

Email: akram@unismuh.ac.id

\section{REFERENCES}

Bakia, M., Shear, L., Toyama, Y., \& Lasseter, A. (2012). Understanding the Implications of Online Learning for Educational Productivity. Office of Educational Technology, US Department of Education.

Barclay, D., Higgins, C., \& Thompson, R. (1995). The Partial Least Square (PLS). Approach to causal modeling: Personal computer adoption and use as an illustration. Technol. Stud, 2(2), 2.

Chen, K.-C., \& Jang, S.-J. (2010). Motivation in online learning: Testing a model of self-determination theory. Computers in Human Behavior, 26(4), 741-752. https://doi.org/10.1016/j.chb.2010.01.011

Cidral, W. A., Oliveira, T., Di Felice, M., \& Aparicio, M. (2018). E-learning success determinants: Brazilian empirical study. Computers \& Education, 122, 273-290. https://doi.org/10.1016/j. compedu.2017.12.001

Fornell, C., \& Larcker, D. F. (1981). Evaluating structural equation models with unobservable variables and measurement error. Journal of Marketing Research, 18(1), 39-50. 
Hair, J. F. (Ed.). (2017). A primer on partial least squares structural equation modeling (PLS-SEM) (Second edition). Sage.

Hartnett, M., St. George, A., \& Dron, J. (2011). Examining motivation in online distance learning environments: Complex, multifaceted and situation-dependent. The International Review of Research in Open and Distributed Learning, 12(6), 20. https://doi.org/10.19173/irrodl.v12i6.1030

Huang, B., \& Hew, K. F. T. (2016). Measuring learners motivation level in massive open online courses. International Journal of Information and Education Technology, 6(10), 759-764.

Jacobi, L. (2018). What Motivates Students in the Online Communication Classroom? An Exploration of Self-Determination Theory. Journal of Educators Online, 15(2), 1-16. https://doi.org/10.9743/ jeo.2018.15.2.1

Jokelova, A. (2013). ARCS motivational model: Theoretical concepts and its use in online courses. 2013 IEEE 11th International Conference on Emerging ELearning Technologies and Applications (ICETA), 189-194. https://doi.org/10.1109/ICETA.2013.6674427

Jöreskog, K. G., \& Sörbom, D. (1993). LISREL 8: Structural equation modeling with the SIMPLIS command language. Scientific Software International.

Keller, J. M. (2008). First principles of motivation to learn and e ${ }^{3}$-learning. Distance Education, 29(2), 175-185. https://doi.org/10.1080/01587910802154970

Keller,J. M. (2017). The MVP Model: Overview and Application: The MVP Model: Overview and Application. New Directions for Teaching and Learning, 2017(152), 13-26. https://doi.org/10.1002/tl.20265

Lai, H.-M., Hsiao, Y.-L., \& Hsieh, P.-J. (2018). The role of motivation, ability, and opportunity in university teachers' continuance use intention for flipped teaching. Computers \& Education, 124, 37-50. https://doi.org/10.1016/j.compedu.2018.05.013

Leedy, P. D., \& Ormrod, J. E. (2016). Practical research: Planning and design (Eleventh edition). Pearson.

Lin, C.-H., Zhang, Y., \& Zheng, B. (2017). The roles of learning strategies and motivation in online language learning: A structural equation modeling analysis. Computers \& Education, 113, 75-85. https:// doi.org/10.1016/j.compedu.2017.05.014

Meyliana, Fernando, E., \& Surjandy. (2019). The Influence of Perceived Risk and Trust in Adoption of FinTech Services in Indonesia. CommIT (Communication \& Information Technology) Journal, 13(1), 31-37.

Mohamad, S. N. M., Salleh, M. A. M., \& Salam, S. (2015). Factors Affecting Lecturers Motivation in Using Online Teaching Tools. Procedia - Social and Behavioral Sciences, 195, 1778-1784. https://doi. org/10.1016/j.sbspro.2015.06.378

Moore, L. L., Grabsch, D. K., \& Rotter, C. (2010). Using Achievement Motivation Theory to Explain Student Participation in a Residential Leadership Learning Community. Journal of Leadership Education, 9(2), 22-34. https://doi.org/10.12806/V9/I2/RF2

Nunnaly, J. C., \& Bernstein, I. (1994). Psychometric theory. McGraw-Hill.

Panigrahi, R., Srivastava, P. R., \& Sharma, D. (2018). Online learning: Adoption, continuance, and learning outcome-A review of literature. International Journal of Information Management, 43, 1-14. https://doi.org/10.1016/j.ijinfomgt.2018.05.005

Raeisi, M., Hadadi, N., Faraji, R., \& Salehian, M. H. (2012). McClelland's motivational needs: A case study of physical education teachers in West Azarbaijan. 4.

Ringle, Sarstedt, \& Straub. (2012). Editor's Comments: A Critical Look at the Use of PLS-SEM in "MIS Quarterly." MIS Quarterly, 36(1), iii. https://doi.org/10.2307/41410402

Santosa, P. I. (2018). Metode Penelitian Kuantitatif-Pengembangan Hipotesis dan Pengujiannya Menggunakan SmartPLS (1st ed.). ANDI. 
Sarsar, F. (2012). Motivation and Online Adult Learners: How do we do that? Anadolu Journal of Educational Sciences International, 8.

Sergis, S., Sampson, D. G., \& Pelliccione, L. (2018a). Investigating the impact of Flipped Classroom on students' learning experiences: A Self-Determination Theory approach. Computers in Human Behavior, 78, 368-378. https://doi.org/10.1016/j.chb.2017.08.011

Sergis, S., Sampson, D. G., \& Pelliccione, L. (2018b). Investigating the impact of Flipped Classroom on students' learning experiences: A Self-Determination Theory approach. Computers in Human Behavior, 78, 368-378. https://doi.org/10.1016/j.chb.2017.08.011

Shih, H.-F., Chen, S.-H. E., Chen, S.-C., \& Wey, S.-C. (2013). The Relationship among Tertiary Level EFL Students' Personality, Online Learning Motivation and Online Learning Satisfaction. Procedia - Social and Behavioral Sciences, 103, 1152-1160. https://doi.org/10.1016/j.sbspro.2013.10.442

Taha, A. M., \& Thang, S. M. (2014). A Preliminary Study on the Influence of a Literature Online Support System (LitOSS) on Malaysian Learners' Motivation. Procedia - Social and Behavioral Sciences, 118, 251-258. https://doi.org/10.1016/j.sbspro.2014.02.034

Turabik, T., \& Baskan, G. A. (2015). The Importance of Motivation Theories in Terms Of Education Systems. Procedia - Social and Behavioral Sciences, 186, 1055-1063. https://doi.org/10.1016/j. sbspro.2015.04.006

Vanslambrouck, S., Zhu, C., Lombaerts, K., Philipsen, B., \& Tondeur, J. (2018). Students' motivation and subjective task value of participating in online and blended learning environments. The Internet and Higher Education, 36, 33-40. https://doi.org/10.1016/j.iheduc.2017.09.002

Vero, E., \& Puka, E. (2017). The Importance of Motivation in an Educational Environment. FORMAZIONE \& INSEGNAMENTO. Rivista Internazionale Di Scienze Dell'educazione e Della Formazione, 15(1), 57-66.

Zainuddin, Z. (2018). Students' learning performance and perceived motivation in gamified flipped-class instruction. Computers $\&$ Education, 126,75-88. https://doi.org/10.1016/j.compedu.2018.07.003 


\section{APPENDIX A}

The Results of the Initial Analysis of the Measurement Model

\begin{tabular}{|c|c|c|c|c|c|c|c|c|c|}
\hline \multirow{2}{*}{$\begin{array}{l}\text { Constructs/ } \\
\text { Factors }\end{array}$} & \multirow{2}{*}{ Items } & \multicolumn{2}{|c|}{ Outer Loadings } & \multicolumn{2}{|c|}{$\begin{array}{l}\text { Composite Reliability } \\
\text { (CR) }\end{array}$} & \multicolumn{2}{|c|}{ Cronbach's Alpha } & \multicolumn{2}{|c|}{$\begin{array}{l}\text { Average Variance } \\
\text { Extracted (AVE) }\end{array}$} \\
\hline & & Lecturers & Students & Lecturers & Students & Lecturers & Students & Lecturers & Students \\
\hline \multirow{5}{*}{$\begin{array}{l}\text { Attention } \\
\text { (At) }\end{array}$} & At1 & 0.577 & 0.764 & 0.820 & 0.883 & 0.731 & 0.834 & 0.484 & 0.602 \\
\hline & At2 & 0.550 & 0.811 & & & & & & \\
\hline & At3 & 0.747 & 0.794 & & & & & & \\
\hline & At4 & 0.880 & 0.810 & & & & & & \\
\hline & At5 & 0.674 & 0.693 & & & & & & \\
\hline \multirow{4}{*}{ Relevance (Rv) } & Rv1 & 0.629 & 0.770 & 0.870 & 0.878 & 0.799 & 0.852 & 0.629 & 0.694 \\
\hline & Rv2 & 0.784 & 0.857 & & & & & & \\
\hline & Rv3 & 0.869 & 0.877 & & & & & & \\
\hline & Rv4 & 0.866 & 0.824 & & & & & & \\
\hline \multirow{5}{*}{$\begin{array}{l}\text { Confidence } \\
\text { (Con) }\end{array}$} & Con1 & 0.755 & 0.745 & 0.876 & 0.845 & 0.824 & 0.771 & 0.589 & 0.522 \\
\hline & Con2 & 0.639 & 0.693 & & & & & & \\
\hline & Con3 & 0.871 & 0.746 & & & & & & \\
\hline & Con4 & 0.768 & 0.714 & & & & & & \\
\hline & Con5 & 0.785 & 0.714 & & & & & & \\
\hline \multirow{4}{*}{$\begin{array}{l}\text { Satisfaction } \\
\text { (Sas) }\end{array}$} & Sas1 & 0.844 & 0.770 & 0.872 & 0.872 & 0.806 & 0.805 & 0.631 & 0.631 \\
\hline & Sas2 & 0.800 & 0.813 & & & & & & \\
\hline & Sas3 & 0.771 & 0.822 & & & & & & \\
\hline & Sas4 & 0.760 & 0.770 & & & & & & \\
\hline \multirow{3}{*}{$\begin{array}{c}\text { Need for } \\
\text { Affiliation (nAff) }\end{array}$} & nAff1 & 0.873 & 0.819 & 0.917 & 0.870 & 0.865 & 0.776 & 0.788 & 0.690 \\
\hline & nAff2 & 0.885 & 0.830 & & & & & & \\
\hline & nAff3 & 0.904 & 0.843 & & & & & & \\
\hline \multirow{4}{*}{$\begin{array}{l}\text { Need for Power } \\
\text { (nPow) }\end{array}$} & nPow1 & 0.536 & 0.779 & 0.831 & 0.882 & 0.728 & 0.820 & 0.558 & 0.651 \\
\hline & nPow2 & 0.797 & 0.830 & & & & & & \\
\hline & nPow3 & 0.832 & 0.859 & & & & & & \\
\hline & nPow4 & 0.785 & $\begin{array}{l}0.756 \text { (not } \\
\text { relevan) }\end{array}$ & & & & & & \\
\hline \multirow{4}{*}{$\begin{array}{c}\text { Need for } \\
\text { Achievement } \\
\text { (nAch) }\end{array}$} & nAch1 & 0.773 & 0.748 & 0.874 & 0.895 & 0.808 & 0.844 & 0.637 & 0.682 \\
\hline & nAch2 & 0.905 & 0.836 & & & & & & \\
\hline & nAch3 & 0.832 & 0.852 & & & & & & \\
\hline & nAch4 & 0.661 & 0.863 & & & & & & \\
\hline \multirow{4}{*}{ Autonomy $(\mathrm{Au})$} & Au1 & 0.833 & 0.810 & 0.841 & 0.868 & 0.748 & 0.797 & 0.574 & 0.624 \\
\hline & Au2 & 0.821 & 0.844 & & & & & & \\
\hline & Au3 & 0.769 & 0.820 & & & & & & \\
\hline & Au4 & 0.583 & 0.676 & & & & & & \\
\hline \multirow{3}{*}{$\begin{array}{l}\text { Comptency } \\
\text { (Com) }\end{array}$} & Com1 & 0.853 & 0.885 & 0.881 & 0.918 & 0.798 & 0.866 & 0.713 & 0.788 \\
\hline & Com2 & 0.809 & 0.906 & & & & & & \\
\hline & Com3 & 0.869 & 0.872 & & & & & & \\
\hline \multirow[t]{4}{*}{ Relatedness (RI) } & $\mathrm{RI} 1$ & 0.648 & 0.766 & 0.869 & 0.878 & 0.797 & 0.817 & 0.625 & 0.642 \\
\hline & $\mathrm{Rl} 2$ & 0.762 & 0.798 & & & & & & \\
\hline & $\mathrm{RI} 3$ & 0.873 & 0.819 & & & & & & \\
\hline & RI4 & 0.831 & 0.821 & & & & & & \\
\hline \multirow{10}{*}{$\begin{array}{l}\text { The motivation } \\
\text { to use the } \\
\text { online learning } \\
\text { system } \\
\text { (MoUl) }\end{array}$} & MuOl1 & 0.761 & 0.789 & 0.935 & 0.943 & 0.922 & 0.932 & 0.591 & 0.622 \\
\hline & $\mathrm{MuOl} 2$ & 0.642 & 0.783 & & & & & & \\
\hline & MuOl3 & 0.725 & 0.791 & & & & & & \\
\hline & $\mathrm{MuOl} 4$ & 0.769 & 0.776 & & & & & & \\
\hline & MuOl5 & 0.797 & 0.764 & & & & & & \\
\hline & MuOl6 & 0.693 & 0.816 & & & & & & \\
\hline & MuOl7 & 0.842 & 0.817 & & & & & & \\
\hline & MuOl8 & 0.805 & 0.788 & & & & & & \\
\hline & MuOl9 & 0.820 & 0.771 & & & & & & \\
\hline & MuOl10 & 0.811 & 0.789 & & & & & & \\
\hline
\end{tabular}

Note. outer loading that is given a thick red color is issued 


\section{APPENDIX B}

\section{The Discriminant Validity-Cross Loadings}

Cross loading -Lecturers

\begin{tabular}{|c|c|c|c|c|c|c|c|c|c|c|c|}
\hline & At & $\mathrm{Au}$ & Com & Con & MuOI & $\mathrm{RI}$ & Rv & Sas & nAch & nAff & nPow \\
\hline At3 & 0,844 & 0,425 & 0,303 & 0,436 & 0,435 & 0,526 & 0,482 & 0,423 & 0,344 & 0,351 & 0,417 \\
\hline At4 & 0,921 & 0,376 & 0,629 & 0,492 & 0,599 & 0,488 & 0,631 & 0,532 & 0,527 & 0,435 & 0,520 \\
\hline Au1 & 0,292 & 0,878 & 0,498 & 0,364 & 0,525 & 0,279 & 0,345 & 0,573 & 0,595 & 0,443 & 0,441 \\
\hline Au2 & 0,458 & 0,848 & 0,503 & 0,571 & 0,590 & 0,490 & 0,424 & 0,636 & 0,502 & 0,454 & 0,480 \\
\hline Au3 & 0,348 & 0,757 & 0,476 & 0,347 & 0,482 & 0,387 & 0,462 & 0,544 & 0,469 & 0,525 & 0,464 \\
\hline Com1 & 0,392 & 0,478 & 0,850 & 0,536 & 0,609 & 0,324 & 0,491 & 0,606 & 0,588 & 0,508 & 0,498 \\
\hline Com2 & 0,473 & 0,470 & 0,811 & 0,392 & 0,626 & 0,334 & 0,573 & 0,662 & 0,581 & 0,467 & 0,530 \\
\hline Com3 & 0,538 & 0,554 & 0,871 & 0,554 & 0,610 & 0,577 & 0,526 & 0,737 & 0,611 & 0,574 & 0,564 \\
\hline Con1 & 0,379 & 0,523 & 0,577 & 0,789 & 0,505 & 0,400 & 0,531 & 0,570 & 0,420 & 0,574 & 0,482 \\
\hline Con3 & 0,471 & 0,403 & 0,496 & 0,873 & 0,524 & 0,340 & 0,564 & 0,525 & 0,434 & 0,505 & 0,417 \\
\hline Con4 & 0,483 & 0,334 & 0,305 & 0,767 & 0,441 & 0,278 & 0,361 & 0,264 & 0,326 & 0,302 & 0,393 \\
\hline Con5 & 0,387 & 0,406 & 0,477 & 0,798 & 0,441 & 0,287 & 0,407 & 0,397 & 0,457 & 0,381 & 0,392 \\
\hline MuOl1 & 0,489 & 0,459 & 0,613 & 0,535 & 0,729 & 0,475 & 0,445 & 0,542 & 0,657 & 0,480 & 0,512 \\
\hline MuOl10 & 0,481 & 0,564 & 0,653 & 0,507 & 0,833 & 0,545 & 0,495 & 0,646 & 0,598 & 0,556 & 0,662 \\
\hline MuOl3 & 0,404 & 0,384 & 0,518 & 0,491 & 0,732 & 0,476 & 0,516 & 0,530 & 0,526 & 0,580 & 0,465 \\
\hline MuOl4 & 0,600 & 0,598 & 0,550 & 0,423 & 0,790 & 0,625 & 0,530 & 0,669 & 0,599 & 0,631 & 0,528 \\
\hline MuOl5 & 0,503 & 0,490 & 0,504 & 0,429 & 0,811 & 0,618 & 0,472 & 0,645 & 0,520 & 0,493 & 0,557 \\
\hline MuOl7 & 0,500 & 0,588 & 0,664 & 0,532 & 0,850 & 0,450 & 0,479 & 0,690 & 0,643 & 0,598 & 0,688 \\
\hline MuOl8 & 0,380 & 0,445 & 0,531 & 0,351 & 0,810 & 0,467 & 0,363 & 0,528 & 0,616 & 0,390 & 0,521 \\
\hline MuOl9 & 0,433 & 0,565 & 0,597 & 0,527 & 0,827 & 0,511 & 0,448 & 0,671 & 0,632 & 0,456 & 0,593 \\
\hline $\mathrm{RI} 2$ & 0,494 & 0,497 & 0,407 & 0,353 & 0,536 & 0,838 & 0,470 & 0,514 & 0,370 & 0,455 & 0,397 \\
\hline $\mathrm{RI} 3$ & 0,522 & 0,437 & 0,479 & 0,381 & 0,638 & 0,933 & 0,552 & 0,624 & 0,424 & 0,555 & 0,516 \\
\hline $\mathrm{R} \mid 4$ & 0,462 & 0,282 & 0,386 & 0,334 & 0,520 & 0,832 & 0,367 & 0,481 & 0,275 & 0,381 & 0,302 \\
\hline Rv2 & 0,564 & 0,512 & 0,525 & 0,351 & 0,463 & 0,474 & 0,830 & 0,607 & 0,327 & 0,445 & 0,404 \\
\hline Rv3 & 0,553 & 0,390 & 0,514 & 0,539 & 0,465 & 0,388 & 0,874 & 0,503 & 0,334 & 0,415 & 0,392 \\
\hline Rv4 & 0,538 & 0,382 & 0,570 & 0,605 & 0,573 & 0,515 & 0,878 & 0,545 & 0,449 & 0,567 & 0,495 \\
\hline Sas1 & 0,593 & 0,659 & 0,723 & 0,603 & 0,739 & 0,560 & 0,558 & 0,846 & 0,691 & 0,645 & 0,650 \\
\hline Sas2 & 0,416 & 0,502 & 0,639 & 0,463 & 0,617 & 0,508 & 0,483 & 0,798 & 0,572 & 0,518 & 0,544 \\
\hline Sas3 & 0,260 & 0,483 & 0,569 & 0,314 & 0,498 & 0,513 & 0,386 & 0,775 & 0,404 & 0,540 & 0,504 \\
\hline Sas4 & 0,411 & 0,583 & 0,559 & 0,350 & 0,567 & 0,399 & 0,588 & 0,757 & 0,487 & 0,454 & 0,415 \\
\hline nAch1 & 0,550 & 0,510 & 0,603 & 0,476 & 0,679 & 0,364 & 0,400 & 0,631 & 0,838 & 0,521 & 0,667 \\
\hline nAch2 & 0,422 & 0,608 & 0,643 & 0,462 & 0,670 & 0,365 & 0,400 & 0,622 & 0,914 & 0,585 & 0,695 \\
\hline nAch3 & 0,299 & 0,484 & 0,545 & 0,357 & 0,560 & 0,328 & 0,306 & 0,508 & 0,801 & 0,427 & 0,595 \\
\hline nAff1 & 0,380 & 0,506 & 0,524 & 0,550 & 0,604 & 0,473 & 0,508 & 0,618 & 0,540 & 0,874 & 0,552 \\
\hline nAff2 & 0,393 & 0,444 & 0,468 & 0,422 & 0,558 & 0,507 & 0,434 & 0,590 & 0,503 & 0,888 & 0,611 \\
\hline nAff3 & 0,422 & 0,556 & 0,632 & 0,513 & 0,584 & 0,459 & 0,544 & 0,614 & 0,564 & 0,901 & 0,528 \\
\hline nPow2 & 0,533 & 0,587 & 0,588 & 0,523 & 0,674 & 0,440 & 0,555 & 0,634 & 0,730 & 0,635 & 0,823 \\
\hline nPow3 & 0,353 & 0,437 & 0,437 & 0,398 & 0,535 & 0,394 & 0,365 & 0,550 & 0,557 & 0,557 & 0,843 \\
\hline nPow4 & 0,414 & 0,303 & 0,515 & 0,346 & 0,527 & 0,320 & 0,278 & 0,457 & 0,589 & 0,327 & 0,823 \\
\hline
\end{tabular}

Note. Attention (At), Relevance (Rv), Confidence (Con), Satisfaction (Sas), need for Affliation (nAff), need for Power (nPow), need for Achievement (nAch), Autonomy (Au), Competency (Com), Relatedness (Rl), Motivation of Use online learning (MoUl) 
Cross loading -Students

\begin{tabular}{|c|c|c|c|c|c|c|c|c|c|c|c|}
\hline & At & $\mathrm{Au}$ & Com & Con & $\mathrm{MuOI}$ & $\mathrm{RI}$ & $\mathrm{Rv}$ & Sas & nAch & nAff & nPow \\
\hline At1 & 0,789 & 0,405 & 0,539 & 0,592 & 0,565 & 0,508 & 0,552 & 0,549 & 0,488 & 0,531 & 0,468 \\
\hline At2 & 0,833 & 0,465 & 0,513 & 0,546 & 0,533 & 0,468 & 0,603 & 0,543 & 0,436 & 0,531 & 0,509 \\
\hline At3 & 0,784 & 0,448 & 0,369 & 0,512 & 0,516 & 0,426 & 0,685 & 0,476 & 0,398 & 0,452 & 0,468 \\
\hline At4 & 0,829 & 0,490 & 0,450 & 0,602 & 0,574 & 0,537 & 0,663 & 0,591 & 0,473 & 0,473 & 0,541 \\
\hline Au1 & 0,498 & 0,858 & 0,505 & 0,601 & 0,649 & 0,498 & 0,569 & 0,515 & 0,636 & 0,610 & 0,598 \\
\hline Au2 & 0,471 & 0,867 & 0,528 & 0,592 & 0,603 & 0,454 & 0,562 & 0,549 & 0,617 & 0,555 & 0,555 \\
\hline Au3 & 0,451 & 0,816 & 0,613 & 0,500 & 0,650 & 0,498 & 0,464 & 0,490 & 0,568 & 0,444 & 0,526 \\
\hline Com1 & 0,505 & 0,550 & 0,886 & 0,538 & 0,616 & 0,606 & 0,477 & 0,577 & 0,620 & 0,510 & 0,551 \\
\hline Com2 & 0,510 & 0,594 & 0,905 & 0,573 & 0,664 & 0,608 & 0,555 & 0,614 & 0,505 & 0,503 & 0,543 \\
\hline Com3 & 0,530 & 0,582 & 0,873 & 0,549 & 0,644 & 0,617 & 0,523 & 0,572 & 0,597 & 0,547 & \begin{tabular}{|l|l|}
0,567 \\
\end{tabular} \\
\hline Con1 & 0,516 & 0,502 & 0,552 & 0,751 & 0,577 & 0,527 & 0,601 & 0,581 & 0,560 & 0,518 & 0,550 \\
\hline Con3 & 0,504 & 0,405 & 0,424 & 0,768 & 0,461 & 0,441 & 0,493 & 0,555 & 0,478 & 0,483 & 0,457 \\
\hline Con4 & 0,532 & 0,568 & 0,407 & 0,741 & 0,599 & 0,376 & 0,566 & 0,462 & 0,497 & 0,604 & 0,551 \\
\hline Con5 & 0,542 & 0,512 & 0,474 & 0,745 & 0,529 & 0,539 & 0,525 & 0,566 & 0,488 & 0,463 & 0,398 \\
\hline MuOI1 & 0,534 & 0,637 & 0,562 & 0,537 & 0,789 & 0,637 & 0,521 & 0,544 & 0,628 & 0,589 & \begin{tabular}{|l|l|}
0,679 \\
\end{tabular} \\
\hline MuOl10 & 0,550 & 0,605 & 0,618 & 0,600 & 0,788 & 0,617 & 0,583 & 0,615 & 0,594 & 0,577 & 0,574 \\
\hline $\mathrm{MuOI} 2$ & 0,575 & 0,624 & 0,620 & 0,630 & 0,783 & 0,592 & 0,569 & 0,577 & 0,655 & 0,614 & 0,609 \\
\hline $\mathrm{MuOI} 3$ & 0,516 & 0,597 & 0,591 & 0,612 & 0,790 & 0,600 & 0,520 & 0,575 & 0,599 & 0,554 & 0,564 \\
\hline $\mathrm{MuOl} 4$ & 0,569 & 0,538 & 0,571 & 0,526 & 0,775 & 0,582 & 0,532 & 0,594 & 0,501 & 0,510 & \begin{tabular}{|l|l|}
0,589 \\
\end{tabular} \\
\hline MuOI5 & 0,475 & 0,478 & 0,523 & 0,544 & 0,764 & 0,581 & 0,536 & 0,594 & 0,513 & 0,481 & 0,509 \\
\hline MuOl6 & 0,541 & 0,563 & 0,624 & 0,566 & 0,816 & 0,585 & 0,569 & 0,615 & 0,607 & 0,570 & 0,602 \\
\hline $\mathrm{MuOl} 7$ & 0,549 & 0,653 & 0,578 & 0,592 & 0,817 & 0,539 & 0,557 & 0,607 & 0,659 & 0,607 & \begin{tabular}{|l|l|}
0,643 \\
\end{tabular} \\
\hline MuOl8 & 0,524 & 0,616 & 0,436 & 0,548 & 0,789 & 0,478 & 0,572 & 0,573 & 0,583 & 0,619 & 0,603 \\
\hline MuOl9 & 0,500 & 0,584 & 0,562 & 0,562 & 0,771 & 0,585 & 0,539 & 0,610 & 0,623 & 0,510 & 0,639 \\
\hline Rl1 & 0,564 & 0,576 & 0,739 & 0,642 & 0,710 & 0,766 & 0,557 & 0,574 & 0,576 & 0,579 & 0,614 \\
\hline $\mathrm{RI} 2$ & 0,430 & 0,374 & 0,467 & 0,414 & 0,503 & 0,798 & 0,414 & 0,520 & 0,400 & 0,367 & 0,433 \\
\hline $\mathrm{Rl} 3$ & 0,458 & 0,411 & 0,458 & 0,443 & 0,509 & 0,819 & 0,362 & 0,526 & 0,418 & 0,449 & 0,462 \\
\hline RI4 & 0,441 & 0,423 & 0,467 & 0,463 & 0,581 & 0,821 & 0,426 & 0,529 & 0,470 & 0,444 & 0,507 \\
\hline Rv1 & 0,589 & 0,537 & 0,412 & 0,564 & 0,540 & 0,384 & 0,770 & 0,457 & 0,490 & 0,490 & 0,536 \\
\hline Rv2 & 0,668 & 0,481 & 0,492 & 0,604 & 0,577 & 0,495 & 0,857 & 0,580 & 0,472 & 0,475 & 0,439 \\
\hline Rv3 & 0,660 & 0,554 & 0,471 & 0,606 & 0,598 & 0,472 & 0,877 & 0,651 & 0,483 & 0,575 & 0,570 \\
\hline Rv4 & 0,655 & 0,515 & 0,567 & 0,659 & 0,603 & 0,518 & 0,824 & 0,584 & 0,572 & 0,517 & 0,515 \\
\hline Sas1 & 0,552 & 0,447 & 0,461 & 0,534 & 0,533 & 0,561 & 0,526 & 0,770 & 0,407 & 0,543 & 0,501 \\
\hline Sas2 & 0,571 & 0,542 & 0,562 & 0,649 & 0,637 & 0,563 & 0,534 & 0,813 & 0,559 & 0,646 & 0,673 \\
\hline Sas3 & 0,551 & 0,478 & 0,536 & 0,543 & 0,611 & 0,531 & 0,583 & 0,822 & 0,488 & 0,594 & 0,529 \\
\hline Sas4 & 0,453 & 0,470 & 0,538 & 0,558 & 0,589 & 0,496 & 0,530 & 0,770 & 0,559 & 0,576 & 0,574 \\
\hline nAch1 & 0,430 & 0,531 & 0,511 & 0,501 & 0,550 & 0,431 & 0,429 & 0,509 & 0,748 & 0,472 & 0,501 \\
\hline nAch2 & 0,411 & 0,539 & 0,530 & 0,564 & 0,615 & 0,552 & 0,457 & 0,502 & 0,836 & 0,553 & 0,539 \\
\hline nAch3 & 0,479 & 0,561 & 0,532 & 0,577 & 0,638 & 0,478 & 0,511 & 0,546 & 0,852 & 0,590 & 0,576 \\
\hline nAch4 & 0,510 & 0,719 & 0,558 & 0,588 & 0,691 & 0,506 & 0,591 & 0,547 & 0,863 & 0,626 & 0,585 \\
\hline nAff1 & 0,588 & 0,564 & 0,555 & 0,665 & 0,635 & 0,537 & 0,544 & 0,721 & 0,596 & 0,819 & 0,699 \\
\hline nAff2 & 0,468 & 0,517 & 0,466 & 0,522 & 0,597 & 0,448 & 0,492 & 0,567 & 0,565 & 0,830 & 0,569 \\
\hline nAff3 & 0,467 & 0,491 & 0,428 & 0,523 & 0,545 & 0,475 & 0,503 & 0,556 & 0,536 & 0,843 & 0,652 \\
\hline nPow1 & 0,481 & 0,525 & 0,497 & 0,518 & 0,642 & 0,536 & 0,520 & 0,532 & 0,495 & 0,686 & 0,848 \\
\hline nPow2 & 0,599 & 0,601 & 0,575 & 0,648 & 0,657 & 0,542 & 0,572 & 0,686 & 0,588 & 0,687 & 0,852 \\
\hline nPow3 & 0,476 & 0,553 & 0,509 & 0,493 & 0,644 & 0,557 & 0,481 & 0,608 & 0,615 & 0,587 & 0,841 \\
\hline
\end{tabular}

Note. Attention (At), Relevance (Rv), Confidence (Con), Satisfaction (Sas), need for Affliation (nAff), need for Power (nPow), need for Achievement (nAch), Autonomy (Au), Competency (Com), Relatedness (Rl), Motivation of Use online learning (MoUl) 


\section{APPENDIX C}

\section{The Valid and Reliable Research Instruments for Lecturers}

Using a four-point scale $1=$ =strongly disagree, $2=$ disagree, $3=$ agree, $4=$ strongly agree, the variables are to be measured by asking lecturers to rate their perceptions of the online learning system in higher education

Strongly disagree $1-2-3-4$ strongly agree

\begin{tabular}{|c|c|c|}
\hline Constructs & Codes & Items/indicators \\
\hline \multirow[t]{2}{*}{ Attention } & At3 & Online learning is more interactive \\
\hline & At4 & Online learning uses learning methods that attract interest \\
\hline \multirow[t]{3}{*}{ Relevance } & Rv2 & Online learning strategies and methods in accordance with learning achievements \\
\hline & Rv3 & Online learning content is relevant to learning outcomes \\
\hline & Rv4 & Adaptive-engaging online learning content \\
\hline \multirow[b]{4}{*}{ Confidence } & Con1 & Online learning increases knowledge \\
\hline & Con3 & Online learning provides a good learning experience \\
\hline & Con4 & Online learning userfriendly learning \\
\hline & Con5 & Online learning provides meaningful feedback \\
\hline \multirow{4}{*}{ Satisfaction } & Sas1 & The convenience of learning through online learning \\
\hline & Sas2 & Obtain awards/recognition from online learning implementation \\
\hline & Sas3 & The pleasure of completing an online learning course \\
\hline & Sas4 & Structured and systematic online learning design \\
\hline \multirow{3}{*}{ Need for Affiliation } & nAff1 & The desire to collaborate through online learning \\
\hline & nAff2 & The desire to fulfil tasks through online learning \\
\hline & nAff3 & The desire to build close relationships through online learning \\
\hline \multirow[t]{3}{*}{ Need for Power } & nPow2 & Desire yourself to use online learning \\
\hline & nPow3 & The desire to obtain the highest position from the use of online learning \\
\hline & nPow4 & The desire to become an online learning system manager at an institution \\
\hline \multirow[b]{3}{*}{$\begin{array}{ll}\text { Need } & \text { for } \\
\text { Achievement } & \end{array}$} & nAch1 & The desire to do something more than ordinary learning \\
\hline & nAch2 & Solve online learning problems \\
\hline & nAch3 & Take personal responsibility in using online learning \\
\hline \multirow[b]{3}{*}{ Autonomy } & Au1 & Online learning is essential and useful \\
\hline & Au2 & Online learning is very flexible \\
\hline & Au3 & Have control of learning to decide what should and should not be done \\
\hline \multirow[b]{3}{*}{ Competency } & Com1 & Having the ability to engage in online learning \\
\hline & Com2 & Able to meet the learning achievements that are the targets of online learning \\
\hline & Com3 & Able to access and spell questions online \\
\hline \multirow[t]{3}{*}{ Relatedness } & $\mathrm{Rl} 2$ & Feel closer to and/or fellow lecturers \\
\hline & $\mathrm{RI} 3$ & Interact more often with friends \\
\hline & $\mathrm{Rl4}$ & Actively contributing throughout the class in group activities \\
\hline \multirow{8}{*}{$\begin{array}{l}\text { The motivation } \\
\text { to use the online } \\
\text { learning system }\end{array}$} & MuOl1 & Attention to online learning \\
\hline & $\mathrm{MuOl3}$ & Trust in online learning \\
\hline & $\mathrm{MuOl} 4$ & Satisfaction with online learning \\
\hline & MuOI5 & The need for affiliation through online learning \\
\hline & MuOI7 & Achievement needs of using online learning \\
\hline & MuOl8 & The autonomy of online learning \\
\hline & MuOl9 & Online learning competence \\
\hline & MuOl10 & Linkages to online learning \\
\hline
\end{tabular}

Note. The loading value of items marked "out" is excluded 


\section{APPENDIX D}

\section{The Valid and Reliable Research Instruments for Students}

Using a four-point scale $1=$ strongly disagree, 2 =disagree, $3=$ agree, $4=$ strongly agree, the variables are to be measured by asking students to rate their perceptions of the online learning system in higher education

Strongly disagree $1-2-3-4$ strongly agree

\begin{tabular}{|c|c|c|}
\hline Constructs & Codes & Items/indicators \\
\hline \multirow[b]{4}{*}{ Attention } & At1 & Online learning system and design attract attention \\
\hline & At2 & Online learning content can build curiosity \\
\hline & At3 & Online learning is more interactive \\
\hline & At4 & Online learning uses learning methods that attract interest \\
\hline \multirow[b]{4}{*}{ Relevance } & Rv1 & Online learning is relevant to the demands of current learning \\
\hline & Rv2 & Online learning strategies and methods in accordance with learning achievements \\
\hline & Rv3 & Online learning content is relevant to learning outcomes \\
\hline & Rv4 & Adaptive-engaging online learning content \\
\hline \multirow[b]{4}{*}{ Confidence } & Con1 & Online learning increases knowledge \\
\hline & Con3 & Online learning provides a good learning experience \\
\hline & Con4 & Online learning userfriendly learning \\
\hline & Con5 & Online learning provides meaningful feedback \\
\hline \multirow{4}{*}{ Satisfaction } & Sas1 & The convenience of learning through online learning \\
\hline & Sas2 & Obtain awards/recognition from online learning implementation \\
\hline & Sas3 & The pleasure of completing an online learning course \\
\hline & Sas4 & Structured and systematic online learning design \\
\hline \multirow{3}{*}{ Need for Affiliation } & nAff1 & The desire to collaborate through online learning \\
\hline & nAff2 & The desire to fulfil tasks through online learning \\
\hline & nAff3 & The desire to build close relationships through online learning \\
\hline \multirow[b]{3}{*}{ Need for Power } & nPow1 & The desire of institutions that require online learning \\
\hline & nPow2 & Desire yourself to use online learning \\
\hline & nPow3 & The desire to obtain the highest position from the use of online learning \\
\hline \multirow{4}{*}{$\begin{array}{l}\text { Need for } \\
\text { Achievement }\end{array}$} & nAch1 & The desire to do something more than ordinary learning \\
\hline & nAch2 & Solve online learning problems \\
\hline & nAch3 & Take personal responsibility in using online learning \\
\hline & nAch4 & Shows good performance in online learning \\
\hline \multirow[b]{3}{*}{ Autonomy } & Au1 & Online learning is essential and useful \\
\hline & Au2 & Online learning is very flexible \\
\hline & Au3 & Have control of learning to decide what should and should not be done \\
\hline \multirow[b]{3}{*}{ Competency } & Com1 & Having the ability to engage in online learning \\
\hline & Com2 & Able to meet the learning achievements that are the targets of online learning \\
\hline & Com3 & Able to access and spell questions online \\
\hline \multirow{4}{*}{ Relatedness } & Rl1 & Collaboration and communication related to learning and assignments through online learning \\
\hline & $\mathrm{RI} 2$ & Feel closer to and/or fellow lecturers \\
\hline & $\mathrm{RI} 3$ & Interact more often with friends \\
\hline & $\mathrm{RI} 4$ & Actively contributing throughout the class in group activities \\
\hline \multirow{10}{*}{$\begin{array}{l}\text { The motivation to use } \\
\text { the online learning } \\
\text { system }\end{array}$} & MuOl1 & Attention to online learning \\
\hline & MuOl2 & The relevance of online learning \\
\hline & MuOl3 & Trust in online learning \\
\hline & MuOl4 & Satisfaction with online learning \\
\hline & MuOl5 & The need for affiliation through online learning \\
\hline & MuOl6 & The need to control through online learning \\
\hline & MuOl7 & Achievement needs of using online learning \\
\hline & MuOl8 & The autonomy of online learning \\
\hline & MuOl9 & Online learning competence \\
\hline & MuOl10 & Linkages to online learning \\
\hline
\end{tabular}

Note. The loading value of items marked "out" is excluded 